Małgorzata Czapiga-Klag

ORCID: 0000-0003-1353-3458

Uniwersytet Wrocławski

https://doi.org/10.19195/1733-5779.38.15

\title{
Narodziny w czasie pandemii - percepcja porodów domowych w kulturze tradycyjnej i we współczesnych mediach
}

Słowa kluczowe: poród domowy, pandemia COVID-19, medykalizacja, ludowa wizja świata

Keywords: home childbirth, COVID-19 pandemic, medicalization, people's vision of the world

Abstrakt: Pandemia COVID-19 wywołała skutki we wszystkich aspektach naszego życia. Ze względu na reżim sanitarny oddziały porodowe w większości szpitali w Polsce i na świecie odmówiły możliwości przeprowadzania porodów rodzinnych. Alternatywą wobec porodu w warunkach szpitalnych jest więc poród domowy, podczas którego decyzję o obecności osób trzecich podejmuje rodząca. Niewątpliwie historia zatacza tu koło, ponieważ na powrót poród ze zdarzenia medycznego staje się wydarzeniem rodzinnym i intymnym. Konotacje związane z porodem domowym w dyskursie publicznym i medialnym są dychotomiczne. Ścierają się tu biegunowe opinie: najczęściej są to bezpieczeństwo/ryzyko i szansa/szaleństwo oraz synonimiczne określenia obu par. Paradoksalnie ta dwudzielność obecna była również w kulturach tradycyjnych i kulturze ludowej, ale tamte wizje świata skupiały się na szeregu zakazów i nakazów związanych z ciążą, porodem i połogiem. Problemem nie było miejsce porodu, bo wiadomo, że musiał się on odbywać w przestrzeni domostw, w społeczności bliskiej ciężarnej, ale to, jak powinien przebiegać. Współcześnie, szczególnie w czasie pandemii, powraca się do praktyki porodu domowego, która ma już diametralnie inny kształt niż dawne, historyczne porody w domu. Jednak emocje, które wywołuje, ciągle oscylują między lękiem a euforią.

\section{Birth during a pandemic - perception of home births in traditional culture and contemporary media}

Abstract: The COVID-19 pandemic has had effects on all aspects of our lives. Due to the sanitary regime, maternity units in most hospitals in Poland and around the world have refused to allow family births. An alternative to hospital birth is home birth, during which the decision on the presence of third parties is made by the woman giving birth. Undoubtedly, the story comes full circle here, as, back from a medical event, childbirth becomes a family and intimate event. The connotations associated with home birth in public and media discourse are dichotomous. Polar opinions clash here: the most common are safety/risk and opportunity/madness, and synonymous 
terms for both pairs. Paradoxically, this duality was also present in traditional cultures and folk culture, but those visions of the world focused on a number of prohibitions and orders related to pregnancy, childbirth and the puerperium. The problem was not the place where the birth took place - because it is known that it had to be in the space of the home, in a close community of the pregnant woman - but how it should take place. Nowadays, especially in times of a pandemic, there is a return to the practice of home birth, which already has a diametrically different shape than the old, historical home birth, but the emotions that it evokes still oscillate between fear and euphoria.

Pandemia COVID-19 wywołała skutki we wszystkich aspektach naszego życia. Kiedy w marcu 2020 roku ogłaszano pierwszy ogólnokrajowy lockdown, nikt jeszcze nie był w stanie wyobrazić sobie, jak głęboko przyjdzie nam przeformułować te codzienne i niecodzienne czynności, rytuały, wydarzenia. Do takich szczególnych, niecodziennych momentów zaliczyć trzeba z pewnością przyjście na świat nowego człowieka, co w czasie pandemii koronawirusa okazało się dla wielu matek, ojców i rodzin zupełnie innym doświadczeniem niż to, na które przygotowywali się od wielu miesięcy. Ze względu na reżim sanitarny oddziały porodowe w większości szpitali w Polsce i na świecie odmówiły możliwości przeprowadzania porodów rodzinnych, czyli takich, w których uczestniczą ojciec przychodzącego na świat dziecka, doula czy inny członek rodziny, na przykład matka rodzącej. Ciężarna pozostawała w tym akcie zdana wyłącznie na personel szpitalny, który jakkolwiek byłby otwarty, życzliwy, wyrozumiały i empatyczny, składał się jednak z obcych ludzi. Oczywiście nie wszystkie kobiety życzą sobie obecności takiej rodzinnej asysty, ale w wypadku planowania porodu, który zostaje w okolicznościach pandemicznych zakazany w takiej formie, sytuacja rodzącej może być w jej odczuciu dość stresująca i niekomfortowa. Alternatywą wobec porodu w warunkach szpitalnych jest więc poród domowy, podczas którego decyzję o obecności osób trzecich podejmuje rodząca. Niewątpliwie historia zatacza tu koło, ponieważ poród ze zdarzenia medycznego staje się na powrót wydarzeniem rodzinnym i intymnym. Wydawać by się mogło, że konotacje związane z porodem domowym powinny być zatem jak najbardziej pozytywne, jednak w dyskursie publicznym i medialnym pojawia się wyraźna dychotomia, w której ścierają się biegunowe opinie o tym, jak postrzega się taki poród domowy: najczęściej są to bezpieczeństwo/ ryzyko i szansa/szaleństwo oraz synonimiczne określenia obu par. Paradoksalnie ta dwudzielność istniała również w kulturach tradycyjnych i kulturze ludowej, ale tamte wizje świata skupiały się na szeregu zakazów i nakazów związanych $\mathrm{z}$ ciążą, porodem i połogiem. Problemem nie było miejsce porodu, bo wiadomo, że musiał się on odbywać w przestrzeni domostw, w społeczności bliskiej ciężarnej. Problemem było to, jak poród powinien przebiegać. Współcześnie, szczególnie w czasie pandemii, powraca się do praktyki porodu domowego, która ma już diametralnie inny kształt niż dawne, historyczne porody w domu. Jednak emocje, które wywołuje, ciągle oscylują między lękiem a euforią. 
Nieprzypadkowo 10 maja 2021 roku odbyła się online konferencja „Poród domowy jako alternatywa porodu rodzinnego w dobie pandemii”, zorganizowana przez Okręgową Izbę Pielęgniarek i Położnych w Bydgoszczy'. Już tytuł pierwszego wystąpienia wskazuje na dychotomię, która obecna jest we współczesnych przekazach medialnych: Poród w domu - zagrożenie czy szansa? (wykład wygłoszony przez prof. UM dr hab. Beatę Piętę, prezes ZG Polskiego Towarzystwa Położnych, kierownik Zakładu Praktycznej Nauki Położnictwa, konsultanta wojewódzkiego w dziedzinie pielęgniarstwa położniczego i ginekologicznego, kierownik Szkoły Rodzenia przy GPSK UM w Poznaniu). Prelegentka wskazała, że dziś w Polsce porody domowe stanowią jedynie $0,2 \%$ wszystkich porodów, więc dość niewielki odsetek, ale zmienia się postrzeganie porodu w domu. Beata Pięta podkreślała, że przez długi czas poród w domu kojarzył się z pewną sytuacją zaskoczenia rodzącej, wydarzeniem nagłym, bez asysty profesjonalistów, podczas gdy wpółcześnie porody takie konotuje się jako coś wręcz elitarnego, ponieważ położna czy położne, ale też inne osoby, są tu na wyłączność rodzącej.

Prelegentka zrelacjonowała też najczęściej pojawiające się argumenty zarówno zwolenników, jak i przeciwników tego typu porodów. Pierwsi wskazują właśnie na powrót do idei starej jak świat — poród powinien być wydarzeniem rodzinnym, intymnym i naturalnym. Unika się wtedy zbędnych procedur i nadmiernej, w opinii wielu, medykalizacji, które obecne są w przestrzeni szpitalnej. Brak ingerencji medycznych, takich jak KTG czy nacięcie krocza, staje się zaś dla dużej grupy rodzących źródłem satysfakcji z samodzielnego postępowania porodu. Przeciwnicy z kolei wskazują na większe prawdopodobne zagrożenie zdrowia i życia rodzącej i noworodka, wynikające przede wszystkich z braku natychmiastowego dostępu do specjalistycznego sprzętu medycznego, gdyby taka interwencja okazała się konieczna.

Z holenderskich badań przeprowadzonych na grupie przeszło 693 tys. kobiet rodzących w latach 2000-2007 wynika, że odsetek interwencji medycznych u wieloródek był znacząco mniejszy w porodach domowych w porównaniu z porodami szpitalnymi. Podobnie niższa była śmiertelność okołoporodowa $\mathrm{w}$ domach ( $0,15 \%$ dla planowanych porodów domowych i $0,18 \%$ dla szpitalnych). Analogiczne dane wynikają $z$ badań przeprowadzanych w Wielkiej Brytanii oraz we Włoszech, o czym szczegółowo mówiła prelegentka. Konkluzja wynikająca z przytaczanych danych statystycznych była taka, że poród w domu może być w wielu przypadkach tak samo bezpieczny jak poród w szpitalu i niesie za sobą mniejszą liczbę interwencji medycznych oraz komplikacji okołoporodowych, jednak wciąż dane te są niewystarczające, a literatura dotycząca porodów domowych bardzo ograniczona.

${ }^{1}$ Zob. https://nipip.pl/porod-domowy-jako-alternatywa-porodu-rodzinnego-w-dobie-pandemii-11-maja-godz-11-00/ (dostęp: 1.06.2021). 
W powszechnej opinii często pokutuje też wątpliwość, czy porody domowe są w ogóle legalne. Na podstawie rozporządzenia Ministra Zdrowia z dnia 16 sierpnia 2018 roku w sprawie standardu organizacyjnego opieki okołoporodowej kobieta ma prawo do wyboru miejsca porodu w warunkach szpitalnych lub pozaszpitalnych. Zmiany takie wynikają z potrzeb, które zgłaszają ciężarne — coraz częściej mówi się też o powrocie do humanizacji porodu, co „oznacza nie tylko stawianie rodzącej w centrum wydarzenia, jakim jest poród, ale i możliwość takiego przeżywania aktu narodzin, który daje kobiecie spełnienie"2. Medykalizacja porodu i głębokie społeczne przeświadczenie, że akt ten wymaga medycznego nadzoru grupy specjalistów, sprawiły, że często pomija się duchowy aspekt porodu.

Podczas porodu przychodzi na świat dziecko, ale rodzi się też matka — zauważa Katarzyna Oleś, położna, współzałożycielka i długoletnia prezeska Stowarzyszenia „Dobrze Urodzeni”, przyjmująca porody domowe od przeszło 30 lat. — Narodziny mogą być głębokim duchowym przeżyciem, czasem naznaczonym doznaniami mistycznymi, czyli takimi, kiedy doświadcza się innych stanów świadomości. Zapewne brzmi to niepokojąco dla niejednego współczesnego człowieka, jednak dostrzegane było od wieków, o czym świadczy bogata symbolika związana z narodzinami ${ }^{3}$.

W wielu kulturach i miejscach na świecie poród był i nadal bywa traktowany jako jeden z rytuałów przejścia. Znane są zapisy obrzędów czasowego wyłączania kobiet ciężarnych ze społeczności, ponieważ izolowana kobieta

jest niebezpieczna i nieczysta albo po prostu dlatego, że jako ciężarna, z fizjologicznego i społecznego punktu widzenia przejściowo znajduje się w stanie anormalnym i trudno się dziwić, że traktuje się ją w taki sposób, w jaki traktuje się chorych, obcych itp. ${ }^{4}$

\section{— konkluduje Arnold van Gennep.}

Zalecenia pielęgnacji chorych, ciężarnych i kobiet w połogu sformułowane były w kulturach tradycyjnych w postaci szeregu zakazów i nakazów. Obejmowały też charakterystyczny rozkład działań magiczno-rytualnych w granicach zarówno czasowych, jak i przestrzennych. Wskazania medycyny ludowej dokładnie określają konieczność i sposoby pielęgnacji chorych — zarówno w ogólnym pojęciu choroby jako stanu szczególnego, jak i w przypadku konkretnych schorzeń, których klasyfikację tworzono nieustannie. W tradycyjnym obrazie świata ,jako stany chorobowe traktowano także menstruację, ciążę, połóg"5, zatem chory, ciężarna i kobieta w połogu należeć będą do jednej grupy — objętych nieczystością, której symptomem była choroba. Objaw chorobowy tłumaczono zazwyczaj kontaktem

2 M. Dziedzic, D. Matuszyk, B. Prażmowska, Poród domowy w opinii położnych, „Problemy Pielęgniarstwa" 19, 2011, nr 2, s. 154.

3 K. Oleś, Poród naturalny, Szczecin 2019, s. 189.

4 A. van Gennep, Obrzędy przejścia. Systematyczne studium ceremonii, przeł. B. Biały, wstęp J. Tokarska-Bakir, Warszawa 2006, s. 64.

5 Z. Libera, Medycyna ludowa. Chłopski rozsądek czy gminna fantazja?, Wrocław 1995, s. 45. 
z przedmiotem, istotą lub zjawiskiem demonicznym ${ }^{6}$, dlatego chorzy obejmowani byli określonymi nakazami i zakazami.

Chory w kulturach tradycyjnych postrzegany był jako zawieszony między dwoma światami. Jego status nie był w pełni ustabilizowany. Z jednej strony przebywał on wciąż wśród żywych, z drugiej zaś jego dolegliwości mogły być wywołane przez czynniki zaświatowe, więc równocześnie otwarty był na mediację z krainą umarłych.

Szczególnie ciężko chorzy, często widzą przed śmiercią, a także m.in. położnice, przeczuwają i widzą śmierć, choroby, zmarłych, pokazuje się im „tamten świat”, opowiadają, co tam widzą. Chory dysponuje zdolnościami podobnymi do trupa ${ }^{7}$.

Często niektóre zachowania chorych i położnic tłumaczono właśnie wpływem krainy umarłych. Należą do nich niecodzienne zachcianki żywieniowe i odczuwanie nieoczekiwanych smaków, co przypisywano nie samemu choremu, ale chorobie, której nadawano status materialny ${ }^{8}$. Zanimizowana lub upersonifikowana choroba zamieszkująca w ciele chorego mogła domagać się coraz to różniejszych potraw albo odwrotnie — ciągle tych samych. Jak zauważa Zbigniew Libera: „Obie te cechy: zmienność — niezróżnicowanie upodobań, charakteryzują nie tylko chorego, chorobę, ale wszystkie istoty »tamtego świata«"9. W przekonaniu mieszkańców wsi chorobie nie należało niczego odmawiać, aby jej przebieg był lżejszy, a ostatecznie - aby skutecznie opuściła chorego. Szkodzące konsekwencje mogło wywołać również niezaspokajanie zachcianek kulinarnych ciężarnej, o których mówiono, że są efektem kuszenia szatana. Zlekceważenie szczególnych upodobań dietetycznych narażało na niebezpieczeństwo zarówno kobietę w ciąży, jak i płód. Nadmierny apetyt będzie też cechował tak zwanych odmieńców, czyli dzieci, które padły ofiarą demonów szkodzących położnicom.

Odmieniony dzieciak był zazwyczaj paskudny, z wielką głową, czasem owłosiony. Nie rósł, nie chodził, bardzo dużo jadł. [...] Wierzono natomiast, iż [odmieńce] pozostawione same w domu wychodziły z kolebki i skrzętnie wyjadały wszystko, co znalazły (niekiedy nawet warzyły sobie strawę), a nie gardziły też i wódką ${ }^{10}$.

Ciężko chorym i umierającym zwykło się nie odmawiać żadnego rodzaju pokarmów, ale lżej chorym i kobietom w ciąży zalecano nie spożywać mięsa. Przekonanie o jego szkodliwości wynikało z dwóch skojarzeń. Po pierwsze, to istotom demonicznym przypisywano upodobanie smaku surowego mięsa, mięsa trupów oraz wszelkich zwierząt kojarzonych z tamtym światem, a więc na przykład jasz-

6 P. Kowalski, Leksykon — znaki świata. Omen, przesąd, znaczenie, Warszawa-Wrocław 1998, s. 54.

7 Z. Libera, op. cit., s. 58-59.

8 P. Kowalski, op. cit., s. 57.

9 Z. Libera, op. cit., s. 48.

10 L.J. Pełka, Polska demonologia ludowa, Warszawa 1987, s. 149-152. 
czurek czy żab ${ }^{11}$. Po drugie, chory, będący w stanie potencjalnej mediacji, nie powinien łamać tabu związanego z przedmiotami zawierającymi pierwiastek życia, $\mathrm{w}$ tym $\mathrm{z}$ mięsem ${ }^{12}$. Pieczone mięso dodatkowo zostaje przetworzone - traci pewne właściwości - dlatego staje się już produktem kultury ${ }^{13}$. Ubytek owych cech mięsa poddanego procesowi pieczenia mógłby spowodować równocześnie ubytki w zdrowiu, na co nie powinno się narażać już osłabionego chorego.

Niektóre choroby (na przykład koklusz, febra, ospa, płonica, róża, ból zębów, kołtun) wymagały unikania wilgoci, co przekładało się na zakaz picia wody, kąpieli, prania; równocześnie zalecano wygrzewanie się i ciepły ubiór. Nieczystość rytualna musiała wyrażać się też w nieczystości fizycznej. W wielu innych przypadkach obmywanie czy kąpiele działały na chorego kojąco i mogły go uleczyć. Szesnastowieczne zielniki zalecające kąpiele lecznicze wymieniają różne ich formy: kąpiele całego ciała — balneum totale, połowy ciała — balneum semicapium, kąpiele miejscowe - balneum topicum ${ }^{14}$. Kąpiel nasiadowa zastosowana po nieudanym porodzie oczyszcza położnicę — „tedy rzecz przyrodzoną mocznie pobudza i też dziecię umarłe wypędza"15. Aby jednak uniknąć komplikacji porodowych, powinno się zażywać specjalnie przygotowanych kąpieli. Stefan Falimirz w dziele $O$ ziołach $i$ ich mocy z 1534 roku zaleca:

Przed zleżeniem dziesięć dni ma do wolnej łaźnie chodzić brzemienna niewiasta. Tam się z brudu wierzchniego omywszy, ma siedzieć w wannie ciepłej wodzie do samego pasa, która woda ma być przyprawiona z temi ziołami odmiękczajączemi, jako jest: ślaz, rumien woniajączy, ogrodny wysoki ślaz, róża czerwona [...], ktemu też kłaść Mercurialem (jest ziele w apteczce), nostrzek; a to wszystko ziele warzyć do wanny i na każdy dzień na noc miałaby się naparzyć po pas brzemienna pani [...] albowiem tym rządzeniem, naciężej dziatki miewającej — snadność a lekkość znamienita stąd przychodzi ${ }^{16}$.

Wśród wschodnich Słowian znany był też zwyczaj tak zwanych zlewin, podczas których rytualnie oczyszczona zostawała zarówno położnica, jak i wykonująca tę czynność wiejska kobieta:

Babka rozbierała położnicę do naga, myła jej ręce i twarz w czystej wodzie, wycierała fartuchem, przy tym mówiła: „oczyszczam twoją duszę od grzechu twojego”. Następnie to samo czyniła położnica babce, ze słowami: „oczyszczam twoje ręce od brudu mojego"17.

11 A. Saloni, Lud rzeszowski. Materyały etnograficzne, „Materyały Antropologiczno-Archeologiczne i Etnograficzne wydawane staraniem Komisyi Antropologicznej Akademii Umiejętności w Krakowie" 10, 1908, s. 130.

12 Z. Libera, op. cit., s. 50.

13 C. Lévi-Strauss, Antropologia strukturalna, przeł. K. Pomian, Warszawa 1970, s. 151-152.

14 J. Szostak, Farmakognozja, farmacja galenowa i aptekarstwo w renesansowych zielnikach polskich, Warszawa 2006, s. 343.

15 S. Falimirz, O ziołach i mocy ich, Kraków 1534, I, k. 9', cyt. za: J. Szostak, op. cit., s. 344.

16 Ibidem.

17 Z. Libera, op. cit., s. 62. 
W przypadku wielu chorób skuteczności w działaniach leczniczych upatrywano w zmywaniu wodą rzeczną lub źródlaną. Wodę należało nabierać zgodnie z prądem. Leczenie na przykład zakażenia jamy ustnej występującego u niemowląt, zwanego „żabą” lub „studzienicą”, polegało na pocieraniu miejsc objętych chorobą szmatką zwilżoną w wodzie przyniesionej przed wschodem słońca. Resztę wody wraz ze szmatką zalecano wylać z powrotem do rzeki, a wraz z tym choroba miała opuścić ciało cierpiącego ${ }^{18}$. Woda miała działanie magiczne także przy odczynianiu uroku, będącego w odczuciu mieszkańców wsi przyczyną wielu groźnych dolegliwości.

Ciężarną ze względu na jej nieokreślony jeszcze stan i przynależność do sfery chaosu obowiązywało zdecydowanie więcej zakazów niż nakazów. Wierzono, że czynności wykonywane przez przyszłą matkę mogą realnie wpłynąć zarówno na przebieg porodu, jak i na usposobienie dziecka. $Z$ tego powodu powinna ona unikać wszelkich działań polegających na związywaniu (bo poród może być skomplikowany, dziecko może urodzić się zaplątane w pępowinę) $)^{19}$. Dziecko mogło przejąć różnego rodzaju defekty wskutek nieprawidłowych zachowań przyszłej matki:

Nie wolno przestraszyć się — gdyż dziecku zostanie jakiś ślad, najczęściej tak zwana mysza (czarna plama), patrzeć na żadne dziwolągi, przechodzić przez dyszel ani siadać na nim. [...] Nie wolno jej było zbierać jaj z kurzych gniazd do podołków, bowiem dzieci mogłyby przychodzić na świat z guzami na brzuchu albo ze strupami na głowach. Podglądanie przez dziurkę od klucza mogło spowodować u dzieci zeza ${ }^{20}$.

Nawet jeśli poród przebiegł pomyślnie, zarówno kobieta, jak i dziecko nadal narażone były na działanie szkodliwych sił. Powszechna praktyka mówiła o zabezpieczeniu położnicy i niemowlęcia przez umieszczenie $\mathrm{w}$ ich otoczeniu apotropeionów, na przykład: „ostrze noża należało wbić w polepę pod łóżkiem, a siekierę postawić w progu ostrzem ku górze" ${ }^{21}$, pod poduszkę wkładano święcony dzwonek lub poświęcone zioła ${ }^{22}$. Te działania o charakterze sensualistycznym zabezpieczały przed podmianą dziecka przez tak zwane mamuny czy boginki. Ani przestrzeń domu, ani to, co na zewnątrz, nie były bezpieczne: „Położnica aż do chrztu dziecka nie mogła wychodzić w pole, bo mogłyby później w jej dom uderzać pioruny"23. Sama położnica też stanowiła zagrożenie.

18 D. Tylkowa, Medycyna ludowa w kulturze wsi Karpat Polskich. Tradycja i współczesność, Wrocław-Warszawa 1989, s. 56.

19 P. Kowalski, op. cit., s. 59.

20 F. Kotula, Przeciw urokom: wierzenia i obrzędy u Podgórzan, Rzeszowiaków, Lasowiaków, Warszawa 1989, s. 78.

${ }^{21}$ H. Mielicka, Kultura obyczajowa mieszkańców wsi kieleckiej XIX i XX wieku, Kielce 1995, s. 158.

22 F. Kotula, op. cit., s. 79.

23 Ibidem, s. 80. 
Do wywodu nie powinna ona właściwie wychodzić z domu, aby na przykład prać w potoku i wyciągać wodę ze studni, gdyż narażona była na działanie sił demonicznych oraz sama mogła rzucać uroki i na przykład spowodować ,zepsucie” wody pitnej $[\ldots]^{24}$.

W przekonaniu ludowym w okresie rajskim ciało ludzkie nie znało żadnych schorzeń i śmierci, a skłonność do chorób jest wynikiem działania diabła — stąd przeświadczenie, że dziecko jeszcze przed narodzeniem ma w sobie słabość, zaczątek potencjalnej choroby, która może ujawnić się po sześciu tygodniach (zatem w okresie, jaki przyjmowano za czas połogu):

aby uchronić dziecko przed konwulsjami, podawali mu zaraz po narodzeniu łajno czarnej krowy rozpuszczone w mleku, po czym następowały wymioty, a z nimi wyrzucenie nieczystości nagromadzonych w okresie życia płodowego ${ }^{25}$.

\section{Zgodnie z inną praktyką:}

W przypadku, kiedy dziecko urodziło się słabe i chorowite, należało zdjąć ze ściany obraz Pana Jezusa Ukrzyżowanego, położyć go na klepisko i podpalić. Kobiety obecne przy porodzie trzymały chore dziecko w dymie nad ogniem powstałym z palącego się obrazu świętego. Wierzono bowiem, że „wielka jest moc boża przez ogień” 26 .

Możliwość kontaktu z zaświatami, szczególnie nasilona podczas porodu i tuż po nim, wymagała nieustannej czujności ze strony położnicy. Często zabraniano jej w tym czasie zasypiać, gdyż wierzono, że może to mieć dramatyczne skutki. „Dla wzmocnienia i odpędzenia snu podawano jej do picia napoje alkoholowe z dodatkiem różnych ziół oraz rosół z szafranem" 27 . W wielu regionach Polski, na przykład w Kieleckiem, po cztero- lub sześciotygodniowym połogu kobieta poddawana była rytualnemu oczyszczeniu, zwanemu wywodem. W tym celu udawała się do kościoła i w przedsionku czekała na księdza, który odmawiając modlitwy i kropiąc święconą wodą, prowadził ją przed ołtarz. Na dobrą wróżbę kobieta powinna trzymać księdza za stułę: miało to zapewnić córce piękne i długie włosy, a synowi - szczęśliwą rękę do wszystkiego ${ }^{28}$.

Dużą rolę w opiece nad położnicami odgrywały ludowe położne, zwane w niektórych regionach Polski „babkami”, „babiculami” czy „hebabami”29. Zajmowały się one odbieraniem porodów, ale też pielęgnacją noworodków, na przykład kąpielami przez pierwsze dni, a także udzielały rad dotyczących chorób kobiecych i dziecięcych. Wielokrotnie, na przykład we wsiach Beskidu Śląskiego, chrzciły dziecko, jeśli pojawiała się groźba komplikacji porodu: ciężarna miała wtedy wypić wodę święconą, a „babka” wypowiadała stosowną formułę: ,ja cię chrzczę jak-

\footnotetext{
24 H. Mielicka, op. cit., s. 165.

25 Z. Libera, op. cit., s. 18.

${ }^{26}$ H. Mielicka, op. cit., s. 159.

27 Ibidem.

28 Ibidem, s. 164-165.

29 D. Tylkowa, op. cit., s. 34.
} 
żeś chłopiec Adam, jak dziewucha Ewa (lub dowolne imiona) w imię Ojca i Syna i Ducha Świętego" 30 .

Połóg był okresem pewnego zawieszenia, funkcjonowania w fazie marginalnej, dlatego niewskazane było też czesanie włosów przez położnicę. W fazie przejściowej, oznaczającej rytualną śmierć, należało wyzbyć się wszelkiej biologiczności jako cechy świata śmiertelników. Złamanie owego zakazu mogłoby skutkować uwięzieniem w owej fazie, tu charakteryzowanej jako chorobowa, i niemożliwością znalezienia się z powrotem wśród zdrowych. Kobieta w ciąży z kolei nie powinna strzyc włosów, aby nie naruszyć kompletności ludzkiego ciała w oczekiwaniu na pełne ukształtowanie się nowego życia ${ }^{31}$.

Jeśli zaś chodzi o porę, to szczególnie skutecznym czasem praktyk uzdrowicielskich była w mniemaniu kultur tradycyjnych noc, postrzegana jako niezróżnicowany chaos śmierci i analogon zaświatów, która z jednej strony była porą demonów, ale $\mathrm{z}$ drugiej mogła też znamionować czas czerpania z mocy zaświatowych, w tym również leczniczych. W nocy choroby się nasilały: „Samopoczucie kołtunowatego [...] pogarsza się wieczorem, w nocy, aż do pierwszego piania koguta"32. Ale rytualne oczyszczenie także podejmowano w nocnych ciemnościach, licząc, że ten czas jest najbardziej predestynowany do odżegnania choroby.

„Przy zamawianiu róży konieczne były różne środki zaradcze. Trzeba wiec było wygłosić formułkę: »Nie będziesz ogniem więcej pustoszyła«, co czyniono przez trzy dni z rzędu po zachodzie słońca [...]"33.

Zachód słońca był okresem granicznym, zatem najodpowiedniejszym na pozbycie się choroby i wyprawienie jej poza obszar ekumeny, w którym funkcjonowała. Wierzono, że można odesłać ją tam, skąd przybyła — do chaosu nieczystości, strefy nieuporządkowanej i niezrozumiałej. Równie graniczny charakter pór najskuteczniejszych na leczenie miały święta, kiedy wzmagała się magiczna moc sacrum.

Podobnie nieprzypadkowe były miejsca, w których chorzy przebywali i poddawani byli praktykom leczniczym. Analogicznie do ustanawiania centrum świata, gdzie znajduje się najmocniejszy punkt mediacji z siłami zaświatowymi, miejscem najbardziej nadającym się do leczenia w przestrzeni domu był środek izby, pod środkową belką pułapu

pośrodku izby, pod krzyżem na tragarzu byli leczeni chorzy z przestrachu, na epilepsję, tu były leczone chore dzieci; tu docucano dziecko pozornie martwo urodzone, środku izby Białorusini ubierali i myli zmarłych; w tym miejscu izby rodziła kobieta u wschodnich i południowych Słowian. Poród i połóg miał miejsce także między piecem a ścianą izby ${ }^{34}$.

30 Ibidem, s. 35.

31 J. Wasilewski, Tabu a paradygmaty etnologii, Warszawa 1989, s. 86.

32 Z. Libera, op. cit., s. 46.

33 H. Biegeleisen, Lecznictwo ludu polskiego, Kraków 1929, s. 133.

34 Z. Libera, op. cit., s. 171-172. 
Niekiedy zabiegi uzdrowicielskie wymagały stworzenia dodatkowych granic. Południowi Słowianie odseparowywali kobietę na czas porodu i połogu. W tym celu otaczali ją zasłoną obszytą czerwonymi nićmi, odpędzającymi złe moce (przez kolor i efekt „zaszycia” — zamknięcia). Działanie to znów ma dwojaki charakter: broni położnicę, ale też przebywających wokół niej, którzy przez jej nieustabilizowany status stają się podatni na ściągnięcie na siebie złego uroku. Te same lęki odnajdziemy w przekazach dotyczących podolskich chłopów, którzy z kolei wokół chorego zakreślali koło święconą kredą, aby choroba nie przeszła na innych ${ }^{35}$.

Poza granicę domu wysyłano chorobę, przenosząc ją na inne obiekty. W wierzeniach Kaszubów suchoty można było wyleczyć, obwiązując nitką najpierw klatkę piersiową chorego, a następnie obwiązując nią drzewo, w ten sposób przekazując schorzenie roślinie ${ }^{36}$. Analogiczny zwyczaj znany był też na przykład na ziemi opolskiej:

Przy guzach piersi stosowano w okolicy Paczkowa następujący zabieg magiczny. Kobieta mająca guz piersi wychodziła bardzo cicho z domu i szła na cmentarz cały czas się modląc i z nikim przy tym nie rozmawiając. Na cmentarzu wyszukiwała kość nieboszczyka i przykładała na chorą pierś. Następnie, również z nikim nie rozmawiając, przynosiła kość do domu. Po pewnym czasie odnosiła ją ,wraz z chorobą" na dawne miejsce ${ }^{37}$.

W praktyce wspomnianej warty podkreślenia jest też wymóg ciszy, często pojawiający się w działaniach leczniczych. Często kobietę do połogu lub znachora do chorego wzywano w tajemnicy, a drogę do pacjenta przemierzano w milczeniu $^{38}$. Miało ono charakter ochronny przed niepożądanymi siłami demonicznymi, a także znamionowało pozyskiwanie jakości zaświatowych przez leczącego (utożsamienie się z cechami „tamtego świata” — bezruchem i ciszą).

Wiele z przytoczonych tu działań łączy elementy obrzędów przejścia i rytuałów ochronnych, które mają chronić kobietę i dziecko przed działaniem złych wpływów oraz zapewnić pomyślność na przyszłość. Podobnie to wygląda u wszystkich Słowian oraz większości ludów Europy, ale także u Indian północnoamerykańskich, u których dla kobiety poród jest „,czasem świętym”39. W wielu społecznościach niezwykle istotni są też pośrednicy obecni przy porodzie,

których zadaniem — jak pisze van Gennep — jest nie tylko neutralizowanie nieczystości lub przyjmowanie na siebie klątw i czarów, ale także służenie za pomost, niejako bramę, ułatwiającą przejście z jednego stanu do drugiego bez wywoływania społecznych wstrząsów czy gwałtownych przerw w życiu jednostki i zbiorowości ${ }^{40}$.

35 Ibidem, s. 59.

36 J. Treder, Kaszubi. Wierzenia i twórczość. Ze Stownika Sychty, Gdańsk 2002, s. 63.

37 Z. Półtorak, Lecznictwo ludowe rodzimej ludności Opolszczyzny, Opole 1989, s. 100.

38 H. Biegeleisen, op. cit., s. 45-46.

39 A. van Gennep, op. cit., s. 66.

40 Ibidem, s. 70. 
Wiele źródeł potwierdza, że funkcja położnej znana była starożytnym Greczynkom i Egipcjankom ${ }^{41}$, w Europie zaś w społecznościach tradycyjnych działały ,babki” i ,mundre”, a od XVII wieku, kiedy powstawały pierwsze szkoły dla położnych, także akuszerki.

Wciąż mam ją przed oczami. Stara kobieta w grubej wełnianej spódnicy, prostej bluzce, ze związanymi włosami, twarzą przeoraną zmarszczkami. Otoczona powszechną czcią i szacunkiem. Ręce przepracowane, ale wciąż zwinne. Kiedy nadchodził czas, szła do chałupy kobiety, z której dochodziły już pierwsze pokrzykiwania. Wyganiała mężczyzn z domostwa, całowała w czoło przyszłą matkę. Rozplatała jej warkocz, zdejmowała wszystkie pierścionki, kolczyki, chustki, żeby nic nie było na niej zawiązane. Kiedy rodzącą trzymały bóle porodowe, otwierała okna, drzwi, szuflady, kufry, żeby rozewrzeć wrota jej łona. Kazała złapać się belek w stropie, dała kieliszek wódki na znieczulenie. Kiedy i to nie pomagało, wysyłała pastucha do cerkwi, żeby pop otworzył bramy świętego miejsca. Żeby sama Matka Boska przybiegła z pomocą rodzącej. Gdy dziecko przychodziło na świat, to ona przecinała pępowinę. To ona zakopywała nieczyste łożysko w progu izby, żeby nikt się nim nie pokalał. Dostawała za swą służbę bochenek chleba albo dwie miary płótna na zapaskę, czasem kilka okraszonych jaj. Nazywano ją też babką, babiculą, mądrą babą, babuszką, akuszerką, a jej sztukę — babieniem ${ }^{42}$.

Poród zawsze konotowany był przede wszystkim jako domena kobieca, dlatego rzadko przy porodach w kulturach tradycyjnych pojawiali się mężczyźni. Wyjątkiem jest tu oczywiście kuwada, która nie była praktykowana powszechnie, czyli

zwyczaj symulowania przez mężczyznę bólów porodowych i połogu odzwierciedlającego poród i połóg żony, interpretowany jako działanie magiczne chroniące potomka lub na płaszczyźnie społecznej jako demonstracja akceptacji ojcostwa ${ }^{43}$.

Babieniem zajmowały się kobiety, najczęściej mające doświadczenie własnych porodów oraz wiedzę zdobytą podczas przyjmowania na świat dzieci w danej społeczności. Poród w kobiecym kręgu mógł generować doświadczenie siostrzanej bliskości, współodczuwania, niekiedy nawet jawić się jako forma pewnego wtajemniczenia.

Zadania towarzyszki porodu są takie same jak partnera rodzącej — zauważa Katarzyna Oleś — jednak kobiety rzadko potrzebują szczegółowego katalogu czynności, raczej nastawiają się na bieżące odczytywanie potrzeb rodzącej i spontaniczne reagowanie na nie ${ }^{44}$.

Od 2015 roku w Polsce rejestrowana jest profesja douli, czyli kobiety zapewniającej ,niemedyczne, emocjonalne, informacyjne i fizyczne wsparcie dla matki i rodziny na czas ciąży, porodu i po porodzie" ${ }^{, 45}$. Wiele kobiet rodzących w anonimowych warunkach szpitala, pozbawionych jest możliwości udziału bliskich w tym wydarzeniu, a szczególnie nasilone restrykcje w tym względzie obowiązywały w kolejnych lockdownach podczas pandemii od 2020 roku. Nie każda ko-

41 Zob. E. Matuszewska, Zarys zawodu położnej, Warszawa 2012.

42 S. Szwed, Mundra, Wołowiec 2014, s. 5.

43 A. van Gennep, op. cit., s. 71.

44 K. Oleś, op. cit., s. 185.

45 http://www.doula.org.pl/ (dostęp: 10.06.2021). 
bieta dobrze radzi sobie z emocjami okołoporodowymi i głębokimi przeżyciami związanymi z przyjściem na świat dziecka. Stowarzyszenie „Doula w Polsce” wychodzi z inicjatywą wsparcia telefonicznego czy online w tym trudnym okresie także dla kobiet rodzących właśnie w szpitalu

Co może zrobić dla Ciebie doula w kontakcie przez telefon/online?

— wysłuchać Twoich obaw, podpowiedzieć jak się relaksować, jak radzić sobie z lękiem,

— porozmawiać o opcjach — w miarę dostępu do informacji i stabilności sytuacji,

— przegadać spakowanie torby do szpitala (co zabrać dla siebie i dziecka na kilka dni być może odizolowania w szpitalu),

— przegadać plan porodu na tę nową rzeczywistość,

— być z Tobą w kontakcie podczas pobytu w szpitalu,

— podpowiedzieć kilka sprawdzonych sposobów samodzielnego radzenia sobie ze skurczami porodowymi oraz metod wspomagających postęp porodu,

— jak sobie pomóc przy porodzie, będąc bez osoby towarzyszącej,

— być dostępnym wsparciem w połogu,

— lub po prostu być wspierająco dostępna, kiedy potrzebujesz ${ }^{46}$.

Wsparcie zaufanej osoby staje się podstawową potrzebą artykułowaną przez kobiety spodziewające się dziecka, a szczególny czas pandemii koronawirusa oraz restrykcje panujące w szpitalach sprawiają, że porody domowe już od stycznia 2021 roku cieszyły się coraz większą popularnością, choć w polskich realiach ciągle marginalizuje się dom jako alternatywę dla szpitala. W reportażu TVN ze stycznia 2021 roku przedstawiono wybrane rodziny, które zdecydowały się na taką formę powitania dziecka na świecie.

Bardzo mi zależało, żeby mój mąż był przy porodzie. Nie chciałam być sama, chciałam żeby mi towarzyszył, widział cud narodzin. Stwierdziłam, że poród domowy to jedyne rozwiązanie, żeby mąż był ze mną od początku do końca i mógł mnie wspierać ${ }^{47}$

— przekonuje bohaterka reportażu. Druga zauważa z kolei:

Wszystko dzieje się swobodnie. Jeśli potrzebowałam pochodzić, nieco chodziłam. Jak potrzebowałam przycupnąć na chwilę, zrobiłam to. Było trochę strachu, ale bardziej przed tym, żeby nie skończyło się transferem do szpitala. Bardzo chciałam urodzić w domu ${ }^{48}$.

Obie przedstawione w reportażu rodziny podkreślają, że taki poród jest również źródłem zupełnie innych przeżyć dla całej rodziny niż poród szpitalny. Kobieta decydująca się rodzić w domu świadomie rezygnuje ze znieczulenia, ale ma prawo swobodnego wyboru na przykład pozycji rodzenia, co nie we wszystkich placówkach szpitalnych jest respektowane. W takich porodach lub ich części uczestniczyć mogą także pozostali członkowie rodziny, na przykład rodzeństwo, co niektórym wydawać się może dość kontrowersyjne, jednak podkreśla się, że

46 Ibidem.

47 Porody domowe w czasie pandemii. „Mocne, głębokie przeżycie”, https://dziendobry.tvn. pl/a/porody-domowe-w-czasie-pandemii-mocne-glebokie-przezycie (dostęp: 10.06.2021).

48 Ibidem. 
w takim wypadku jest to naturalny bieg zdarzeń — w relacjach z porodów często pojawia się informacja, że inne dziecko czy dzieci spały za ścianą, gdy na świat przychodzili brat czy siostra ${ }^{49}$. Rzadko takie porody są efektem opieszałości rodziców w drodze do szpitala, a raczej wyborem podjętym z pełną świadomością możliwych konsekwencji. Do pewnego momentu rodzina jest najczęściej sama, a kolejnej fazie porodu towarzyszy wcześnie wybrana i umówiona położna. Porody domowe w Polsce nie są refundowane przez NFZ, dlatego koszt takiej usługi waha się w granicach 3-5 tys. złotych. Porody domowe są czymś normalnym, akceptowalnym, a także są częściowo lub całkowicie refundowane w innych krajach, chociażby takich jak Dania, Szwecja, Holandia, Austria, Wielka Brytania, Kanada. Okazuje się, że szereg polskich położnych świadczy takie wsparcie i dość pozytywnie wypowiada się na temat porodów domowych. Badania na grupie blisko 160 polskich położnych przynoszą ciekawe wyniki:

1. Zdecydowana większość respondentek uznaje dom jako alternatywne miejsce porodu, a połowa określa jako bezpieczne.

2. Wśród badanych $22,5 \%$ osób jest zdecydowanych podjąć się prowadzenia porodów domowych. Położne te uważają poród domowy za bezpieczną i dobrą alternatywę porodu szpitalnego.

3. Analiza materiału badawczego wskazuje na istotnie statystycznie wyższy poziom deklaracji bezpieczeństwa porodu domowego przez położne licencjonowane lub dyplomowane.

4. Położne deklarujące chęć prowadzenia porodów domowych to osoby ze stażem pracy w sali porodowej 6-10 lat i ponad 10 lat.

5. Opinia o bezpieczeństwie porodu domowego nie zależy od wieku i ogólnego stażu pracy badanych.

6. W opinii badanych położnych bezpieczeństwo porodu w domu zależy od kwalifikacji zawodowych, stażu pracy i doświadczenia w pracy na sali porodowej.

7. Bezpieczeństwo porodu domowego wymaga też rozwiązań systemowych zapewniających współpracę położnej przyjmującej porody w domu z zespołem terapeutycznym w szpitalu ${ }^{50}$.

Badane respondentki podkreślały, że dla każdej położnej podejmującej się uczestnictwa w porodzie domowym bardzo ważne jest dokładne rozważenie sytuacji położniczej i zakwalifikowanie pacjentki do grupy niskiego ryzyka. Nie każda ciąża może zakończyć się porodem domowym, a kwestionariusz kwalifikacji ciężarnej zawsze leży po stronie położnej. Wciąż jednak pokutuje przeświadczenie o ogromnym ryzyku takiego porodu

Istnieje [...] silnie utrwalona informacja społeczna o konieczności odbywania porodu wyłącznie w warunkach szpitalnych i wynikająca z tego opinia, że nie jest on czymś naturalnym, fizjologicznym, lecz związanym $\mathrm{z}$ niebezpieczeństwem, wymagającym bacznej obserwacji $\mathrm{i}$,prowadzenia" 51 .

Nietrudno natrafić na kolejne materiały w sieci, w których podkreśla się dychotomię wpisaną w percepcję porodów domowych. Dla przykładu wystarczy przy-

\footnotetext{
49 Ibidem.

50 M. Dziedzic, D. Matuszyk, B. Prażmowska, op. cit., s. 161.

51 Ibidem.
} 
wołać choćby takie tytuły i leady: Poród domowy w czasie pandemii - szaleństwo czy bezpieczna alternatywa dla szpitala? ${ }^{52}$; Poród w domu nie dla każdego! Ile trzeba zaplacić za ten komfort ${ }^{53}$; Poród w domu - czy to duże ryzyko? ${ }^{54}$; Czy $w$ domu bezpiecznie? Chyba nie ${ }^{55}$. Materiały takie najczęściej nie opierają się na rzetelnych badaniach dotyczących tematu, lecz jedynie podsycają stereotypowy obraz porodu domowego kojarzonego z niebezpieczeństwem, niepotrzebnym ryzykiem, chwilową modą czy brakiem odpowiedzialności.

Ciekawe, że często same emocje porodowe, niezależnie od miejsca porodu, konotowane są pejoratywnie. Wskazuje na to na przykład w swoich badaniach z 2020 roku doktor nauk o zdrowiu Magdalena Słoma: w badaniu z udziałem przeszło 400 kobiet $60 \%$ respondentek utożsamiało poród $\mathrm{z}$ bólem, a $40 \%$ z pozytywnymi emocjami, radością ${ }^{56}$. W tych samych badaniach pojawiło się też pytanie o legalność porodu domowego w Polsce i o ile wśród kobiet, które mają takie doświadczenie za sobą, o legalności przekonanych było $90 \%$ badanych, o tyle w grupach kobiet rodzących w szpitalach i prywatnych klinikach przekonanie to plasowało się na poziomie $60-70 \%$, co wskazuje na niską społeczną świadomość na temat prawnych uwarunkowań porodów domowych. W porównywanych grupach występowały też zupełnie odmienne poglądy na temat bezpieczeństwa porodów domowych

Odsetek osób o poglądach wyrażających się o porodach domowych jako bezpiecznym rozwiązaniu jest bardzo mały wśród rodzących w prywatnej klinice (19\%), połowę wyższy był w szpitalu (37,6\%), wobec niemal całkowitej jednomyślności wśród kobiet, które mają za sobą poród domowy $(99,4 \%)$ czy w domu narodzin $(100 \%)^{57}$.

Jak zauważa autorka badań:

Samoocena wiedzy o porodach domowych zależała w bardzo wyraźny sposób od faktu odbycia porodu domowego lub w domu narodzin. Wynika stąd ważna konkluzja, że negatywny stosunek do porodów domowych kobiet rodzących w szpitalach czy klinikach wynika po części nie z racjonalnych przesłanek, ale $\mathrm{z}$ braku wiedzy o tej formie porodów ${ }^{58}$.

52 Poród domowy w czasie pandemii - szaleństwo czy bezpieczna alternatywa dla szpitala?, https://poofi.com/pl/porod-domowy-w-czasie-pandemii-szalenstwo-czy-bezpieczna-alternatywa-dla-szpitala (dostęp: 10.06.2021).

${ }^{53}$ M. Oszczepalińska, Poród w domu nie dla każdego! Ile trzeba zapłacić za ten komfort?, https://mamotoja.pl/porod-w-domu-ile-kosztuje-i-jak-wyglada-naturalny-porod-domowy,gdzie-rodzic-artykul,26251,rlp1.html (dostęp: 10.06.2021).

54 Poród w domu - czy to duże ryzyko?, https://www.edziecko.pl/ciaza_i_porod/7,79332, 20387912,porod-w-domu-czy-to-duze-ryzyko.html (dostęp: 10.06.2021).

55 Ch.J. Lockwood, Czy w domu bezpiecznie? Chyba nie, https://podyplomie.pl/publish/system/ articles/pdfarticles/000/012/941/original/36-37.pdf?1472037623 (dostęp: 10.06.2021).

56 M. Słoma, E. Krajewska-Kułak, K. Krajewska-Ferishah, Miejsce porodu a percepcja porodu domowego oraz jakości narodzin, Białystok 2020, s. 156.

57 Ibidem, s. 110-111.

58 Ibidem, s. 119-120. 
Zapytano też ankietowane o źródła wiedzy na temat porodów domowych i wyniki wskazują, że zdecydowana większość wiedzę tę czerpała z internetu, ale

częstość korzystania z większości wymienianych w ankiecie źródeł wiedzy na temat porodów domowych zależała w statystycznie istotny sposób od faktu odbycia takiego porodu. Chociaż niektóre źródła - czasopisma, telewizja były dla odmiany częściej wskazywane przez kobiety rodzące w szpitalu czy prywatnej klinice ${ }^{59}$.

Ciekawe zestawienie wynikało też z reakcji bliskich na wieść o planowanym porodzie domowym. Autorka podkreśla, że

występowały znaczące różnice w ocenie reakcji rodziny na chęć odbycia porodu domowego przez ankietowaną kobietę - w grupie kobiet, które ostatni poród odbyły włánie w domu, ale także i w domu narodzin, było ok. $50 \%$ wskazań na reakcję pozytywną, zaś w dwóch pozostałych grupach oczekiwania pozytywnych reakcji występowały sporadycznie (poniżej $10 \%$ odpowiedzi) ${ }^{60}$.

Skoro internet staje się głównym źródłem wiedzy na temat porodów domowych, nie powinien dziwić dychotomiczny ich obraz, bo obok rzetelnych badań, przez które nie każdy ma siłę i ochotę przebrnąć, czy relacji samych rodzących w domach, w większości wypowiadających się pozytywnie o tej formie narodzin, istnieje mnóstwo materiałów napędzających lęk i wątpliwości. Jednym z takich kontrowersyjnych obrazów jest film Cząstki kobiety, dostępny na platformie Netflix od 7 stycznia 2021 roku, który od premiery wywołuje niesłabnące dyskusje. Dramat filmowy z 2020 roku w reżyserii Kornéla Mundruczó, zrealizowany według scenariusza Katy Wéber, jest fabułą opartą na własnych doświadczeniach twórców, będących prywatnie parą, którą również dotknęła tragedia utraty dziecka. Kiedy Mundruczó szukał pomysłów na spektakl teatralny, natrafił na fragmenty notatek w zeszycie Katy, które nosiły tytuł Cząstki kobiety. To one stały się inspiracją sztuki teatralnej, a ta z kolei była kanwą scenariusza filmowego. Główny wątek dotyczyć miał traumy, z jaką przychodzi się mierzyć rodzicom po stracie dziecka. W tym konkretnym przypadku jednak do śmierci noworodka dochodzi po porodzie domowym, którego rozbudowana i bardzo sugestywna scena trwa blisko 30 minut. Niedługo po premierze pojawiły się liczne głosy krytyczne podkreślające, że produkcja demonizuje tę formę porodu. Margo Sikora-Borecka z fundacji Rodzić po Ludzku komentuje

Pamiętajmy, że film „Cząstki kobiety” to reżyserska wizja porodu domowego, a nie film dokumentalny. Rozumiemy, że trudności w odbiorze mogą mieć widzowie, którzy widzą poród domowy i w jego tle śmierć dziecka, z niewiadomych przyczyn. To temat bardzo trudny, nieporuszany w opiece okołoporodowej, ale to nie znaczy, że śmierci dzieci i kobiet nie mają miejsca, bo, mimo że dużo rzadziej niż dziesiątki lat temu, to nadal się zdarzają, bywa, że bez jasnego wytłumaczenia $^{61}$.

59 Ibidem, s. 120-121.

60 Ibidem, s. 121.

${ }^{61}$ G. Jelonek, Przez film Cząstki kobiety na Netfliksie kobiety będa rezygnować z porodów $w$ domu? Produkcja w ogniu krytyki. „Demonizuje porody domowe”, „Głos Wielkopolski” 
Poronienia i śmierć dziecka są niezwykle trudnymi doświadczeniami i dla rodziców, i dla środowiska, a także ciągle kulturowo tabuizowanymi tematami, dlatego film Mundruczó już w punkcie wyjścia jest przekazem bardzo wymagającym. Kreacje głównych bohaterów, granych przez Vanessę Kirby i Shię LaBeouf, zasługują na ogromne docenienie. Sama Kirby, która nigdy nie rodziła, przygotowywała się do roli, obserwując pracę położnych na oddziałach szpitalnych oraz w domach, aby jak najlepiej zrozumieć emocje towarzyszące ciężarnym w momencie porodu, a sama scena porodu nakręcona została w prawdziwym domu i wystąpiło w niej prawdziwe dziecko z wygenerowaną komputerowo pępowiną ${ }^{62}$. Wszystko to sprawia, że chwilami nietrudno ulec złudzeniu, iż oglądamy dokument, a nie fabułę, a co za tym idzie - może to w dużym stopniu wpłynąć negatywnie na ocenę samego porodu domowego i zasadności podjęcia takiej decyzji przez przyszłych rodziców.

Podobnie ambiwalentne emocje budzi fotoreportaż Jackie Molloy opublikowany w „National Geographic”, poświęcony porodowi domowemu, na który w takiej formie z powodu pandemii zdecydowała się trzydziestotrzyletnia Kimberly Bonsignore $^{63}$. Główną motywacją nowojorczanki była potrzeba obecności partnera i starszej córki przy przywitaniu na świecie kolejnego członka rodziny. Fotografka dokumentowała bardzo intymne chwile przebiegu porodu od pierwszych skurczów matki, przez pomoc douli, która przygotowywała basen porodowy w salonie, aż po przybycie położnej i wszelkie działania podejmowane kolejno podczas narodzin dziecka. Postronnemu obserwatorowi już sam fakt „,podglądania” tak bardzo rodzinnych wydarzeń, przepełnionych emocjami, które wyzierają z każdej fotografii, wydawać się może czymś szokującym, ale reportaż ten może również wstrząsnąć ze względu na wydarzenia drugiej części porodu, tak dokładnie uwiecznione przez autorkę. Pierwsze trudności w postaci nagłego braku ciepłej wody i konieczność napełniania basenu przez doulę $\mathrm{w}$ masce garnkami z podgrzewaną na kuchence wodą nie zapowiadają jeszcze tych prawdziwych komplikacji, które nastąpią kilkadziesiąt minut później. Po pięknych scenach, kiedy córka Kimberly Bonsignore, Sativa, bawi się zabawkami w wodzie basenu, w którym leży mama, widzimy portrety coraz bardziej wykrzywionej w bólach twarzy Kimberly, podczas gdy mała córeczka, przestraszona krzykami matki, zakrywa sobie uszy.

13.01.2021. https://gloswielkopolski.pl/przez-film-czastki-kobiety-na-netfliksie-kobiety-beda-rezygnowac-z-porodow-w-domu-produkcja-w-ogniu-krytyki-demonizuje-porody/ar/c6-15387115 (dostęp: 10.06.2021).

${ }^{6}$ H. Kelly, Pieces of a Woman Hinges on One Heaving, Tremendous Home Birth-Scene, https:// www.vulture.com/2021/01/how-pieces-of-a-woman-filmed-the-home-birth-scene.html (dostęp: 10.06.2021).

63 J. Hurlock, Narodziny w czasie pandemii. Zobacz intymny fotoreportaż z porodu domowego, https://www.national-geographic.pl/artykul/narodziny-w-czasie-pandemii-zobacz-intymny-fotoreportaz-z-porodu-domowego (dostęp: 10.06.2021). 
Kiedy dziecko zaczęło pojawiać się na świecie, położna szybko zorientowała się, że pępowina owinęła się wokół szyi dziewczynki. Wbrew powszechnemu mniemaniu nie jest to bardzo nietypowa i rzadko pojawiająca się sytuacja, ponieważ rejestruje się ją prawie w $40 \%$ porodów. Mimo manewrów odwinięcia pępowiny przez położną dziecko po pojawieniu się na świecie było sine i wiotkie, dlatego „Muhlhahn zdjęła maskę i natychmiast rozpoczęła resuscytację. W pokoju panowała cisza, słychać było tylko jej odmierzane oddechy i jakby gdzieś w tle I Need a Miracle grupy Grateful Dead"64. Zdjęcia uwieczniające te dramatyczne chwile są niezwykle przejmujące - bezwładne, nieprzytomne dziecko w rękach położnej, która przeprowadza sztuczne oddychanie i masaż klatki piersiowej, pozostaje w pamięci oglądających na długo. Po dwóch minutach reanimacji w końcu słychać głos nowo narodzonej Suzette, a na twarzach rodziców i położnej widać mieszaninę ulgi i euforii. Na kolejnej fotografii zawinięty w ręcznik noworodek, cały jeszcze w mazi płodowej, z ufnością spogląda w oczy trzymającego go w objęciach ojca. Rodzice stwierdzają, że poród mimo chwilowych komplikacji był w ich ocenie radosny i ekscytujący — „Jest to o wiele bardziej organiczne doświadczenie niż w szpitalu"65.

Choć nowojorska historia Suzette Bonsignore zakończyła się dobrze i rodzina również $\mathrm{w}$ ostatecznym rozrachunku była zadowolona $\mathrm{z}$ wyboru porodu domowego, silnie oddziałujące na wyobraźnię obrazy z akcji porodowej sprawiają, że znów otrzymujemy dość ambiwalentny obraz i w opinii wielu decyzja o porodzie w domu oceniana jest jako nieodpowiedzialna i jako niepotrzebne ryzykowanie zdrowiem i życiem matki i dziecka.

W Polsce z ,propagandą” obecną także w dyskursie lekarskim, przekonującą, że „poród to proces tak dynamiczny, że w żadnym momencie nie można zagwarantować, że przebiegająca prawidłowo fizjologicznie akcja nie przerodzi się w poważną, zagrażającą życiu bądź zdrowiu matki lub dziecka, patologię"66, walczy fundacja Rodzić po Ludzku, która śledzi badania i opinie specjalistów z całego świata poświęcone między innymi porodom domowym. Według tych danych

liczba interwencji medycznych (takich jak nacięcie krocza, kroplówka z oksytocyną, przebicie pęcherza, użycie vacuum lub kleszczy, podanie środków znieczulających) w przypadku porodów domowych jest radykalnie niższa. Jednocześnie $\mathrm{w}$ badaniach nie odnotowano, by w przypadku porodu w domu wzrastał odsetek śmierci okołoporodowej noworodków bądź matek, a także, by dzieci urodzone w domu częściej wymagały resuscytacji lub intensywnej terapii lub miały niższą punktację w skali Apgar ${ }^{67}$.

64 Ibidem.

65 Ibidem.

${ }^{66}$ Czy to bezpieczne?, https://www.rodzicpoludzku.pl/porod-w-domu/czy-to-bezpieczne.html (dostęp: 10.06.2021).

67 Ibidem. 
Czas pandemii COVID-19 sprawił, że nasze poczucie pewności, bezpieczeństwa, sprawczości zostało bardzo mocno zachwiane. Dostęp do wielu dóbr i usług stał się ograniczony albo wręcz niemożliwy. Szaleńcze tempo życia, nieograniczone możliwości przemieszczania się w przestrzeni, niereglamentowana konsumpcja, które do momentu wybuchu epidemii jawiły się jako zdobycze nie do naruszenia, nagle przestały obowiązywać. W wielu przypadkach to, co dawniej zaliczylibyśmy do oczywistych praw, teraz stawało się przywilejem. Niełatwe zadanie mierzenia się z nową rzeczywistością stanęło przed kobietami spodziewającymi się dziecka i ich rodzinami. Wielokrotnie to zawieszenie jasnych taksonomicznych podziałów i imponderabiliów „,w czasach zarazy” wytrącało je z komfortu, spokoju i autokontroli. Zamykane szpitale, przemianowywane na jednoimienne, zaostrzany reżim sanitarny, w końcu czasowe zakazy porodów rodzinnych wywołały duże zainteresowanie powrotem do porodu naturalnego w warunkach domowych. Już zasadność samego porodu naturalnego, definiowanego tu jako poród zdrowej kobiety rodzącej zdrowe dziecko, samoistnie o czasie, przebiegający fizjologicznie bez interwencji medycznych, bywa dziś podważana. Wiek XXI jawił się przecież jako epoka rozumu, ogromnych możliwości technologicznych i rozwoju medycyny, więc dlaczego nie zrezygnować z nieprzewidywalności czasu i miejsca, z bolesnego i nierzadko długotrwałego procesu na rzecz cesarskiego cięcia wykonanego w pełnym znieczuleniu w określonych wcześniej miejscu i terminie? Nie ma jednej i ostatecznej odpowiedzi, ale w wielu przypadkach poród fizjologiczny to wydarzenie, w którym

to kobieta jest kapitanem i samodzielnie trzyma stery w swoich rękach, a wszyscy wokół działają — za jej przyzwoleniem — jedynie po to, by wspierać proces narodzin. Rodząca aktywna jest przede wszystkim w kontakcie ze sobą samą, a dopiero potem z osobami wokół niej. To ona sama wie, czuje, co jest dla niej najlepsze, i robi to, a nie biernie realizuje sugestie otoczenia. [...] Wzięcie swojej części odpowiedzialności może być dla matki niełatwe, jednak nie ma innej drogi do świadomego rodzenia. W zamian za podjęcie tego wysiłku można dostać olbrzymią satysfakcję, poczucie mocy i sprawczości, wiedzę o swoich możliwościach i granicach, spełnienie. Nawet trudne doświadczenia porodowe łatwiej zaakceptować i uczynić fundamentem czegoś dobrego. To najlepszy sposób wkroczenia w rodzicielstwo, prawdziwy rytuał przejścia ${ }^{68}$.

Paradoksalnie czas pandemii na nowo otworzył dyskusję nad sensownością porodów domowych w XXI wieku, co w dużym stopniu było pewnego rodzaju zwrotem ku przeszłości. Wiadomo z kolei, że kobiety od zawsze rodziły w miejscach, w których czuły się bezpiecznie. Już malowidła naścienne z epoki kamiennej przedstawiają sceny porodów, które odbywały się w miejscach odosobnienia, ciszy i ciepła, w asyście kręgu kobiet danej społeczności ${ }^{69}$. Ten niezwykle istotny czynnik konieczności poczucia bezpieczeństwa w momencie wydawania na świat potomka znany był zatem od czasów prehistorycznych i jest rodzajem łącznika

68 K. Oleś, op. cit., s. 195.

69 Zob. J. Towler, J. Bramall, Midwives in history and society, London-Dover 1986. 
przez wszystkie epoki aż do współczesności. Pandemia przeformułowała takie pojęcia jak spokój, komfort, bezpieczeństwo, pewność, znosząc ich typowe definicje oraz pokazując, na jak kruchych fundamentach zbudowane były wyobrażenia o sile, sprawczości i mocy człowieka. Odesłała tym samym do głęboko tkwiących w nas antropologicznych lęków, które przybrały współcześnie tylko nowe formy. Rozczarowanie rozwojem technologii i zdobyczami medycyny, które w zderzeniu z COVID-19 pozostały przynajmniej do pewnego momentu bezradne, sprawiło, że refleksja nad podmiotowością i godnością człowieka uaktualniła się w aspekcie porodów. Porody domowe stały się alternatywne wobec porodów szpitalnych, a także zwrotem ku korzeniom, ku działaniom bardziej instynktownym niż intelektualnym. W dyskursie społecznym i medialnym nadal jednak jest dychotomiczny obraz porodów domowych: obok głosów o zbędnym ryzyku, nieodpowiedzialności i braku rozsądku pojawia się ocena porodu w warunkach domowych jako głęboko intuicyjnego przeżycia o głęboko duchowym wymiarze — narodziny zawsze wpisywały się w szereg pytań o początek i koniec ludzkiej egzystencji, jej sensowność, perspektywy. Nowożytność wraz z triumfem medycyny coraz bardziej deprecjonowała całą sferę symboliczną i rytualną związaną z powitaniem potomka na świecie. Dziś paradoksalnie pandemia COVID-19, podważając zaufanie do systemu opieki zdrowotnej, stała się czynnikiem, który odsyłać będzie znów do porodów w przestrzeni domowej.

\section{Bibliografia}

Biegeleisen H., Lecznictwo ludu polskiego, Kraków 1929.

Biegeleisen H., Matka i dziecko: w obrzędach, wierzeniach i zwyczajach ludu polskiego, Lwów 1927.

Dziedzic M., Matuszyk D., Prażmowska B., Poród domowy w opinii położnych, „Problemy Pielęgniarstwa" 19, 2011, nr 2.

Gennep A. van, Obrzędy przejścia. Systematyczne studium ceremonii, przeł. B. Biały, wstęp J. Tokarska-Bakir, Warszawa 2006.

Kotula F., Przeciw urokom: wierzenia i obrzędy u Podgórzan, Rzeszowiaków, Lasowiaków, Warszawa 1989.

Kowalski P., Leksykon — znaki świata. Omen, przesad, znaczenie, Warszawa-Wrocław 1998.

Kuchowicz Z., Warunki zdrowotne wsi i miasteczek województw tęczyckiego i sieradzkiego w XVIII wieku, Łódź 1961.

Lévi-Strauss C., Antropologia strukturalna, przeł. K. Pomian, Warszawa 1970.

Libera Z., Medycyna ludowa. Chłopski rozsądek czy gminna fantazja?, Wrocław 1995.

Matuszewska E., Zarys zawodu położnej, Warszawa 2012.

Mielicka H., Kultura obyczajowa mieszkańców wsi kieleckiej XIX i XX wieku, Kielce 1995.

Oleś K., Poród naturalny, Szczecin 2019.

Pełka L.J., Polska demonologia ludowa, Warszawa 1987.

Półtorak Z., Lecznictwo ludowe rodzimej ludności Opolszczyzny, Opole 1989.

Saloni A., Lud rzeszowski. Materyaty etnograficzne, „Materyały Antropologiczno-Archeologiczne i Etnograficzne wydawane staraniem Komisyi Antropologicznej Akademii Umiejętności w Krakowie" 10, 1908. 
Słoma M., Krajewska-Kułak E., Krajewska-Ferishah K., Miejsce porodu a percepcja porodu domowego oraz jakości narodzin, Białystok 2020.

Stomma L., Mit Alkmeny, „Etnografia Polska” 20, 1976, z. 1.

Szostak J., Farmakognozja, farmacja galenowa i aptekarstwo w renesansowych zielnikach polskich, Warszawa 2006.

Szwed S., Mundra, Wołowiec 2014.

Towler J., Bramall J., Midwives in history and society, London-Dover 1986.

Treder J., Kaszubi. Wierzenia i twórczość. Ze Stownika Sychty, Gdańsk 2002.

Tylkowa D., Medycyna ludowa w kulturze wsi Karpat Polskich. Tradycja i współczesność, Wrocław-Warszawa 1989.

Tylkowa D., Zdobywanie i użytkowanie wody we wsiach Beskidu Ślaskiego, Warszawa 1978.

Wasilewski J., Tabu a paradygmaty etnologii, Warszawa 1989.

\section{Źródła internetowe}

Czy to bezpieczne?, https://www.rodzicpoludzku.pl/porod-w-domu/czy-to-bezpieczne.html.

https://nipip.pl/porod-domowy-jako-alternatywa-porodu-rodzinnego-w-dobie-pandemii-11-maja-godz-11-00/.

http://www.doula.org.pl/.

Hurlock J., Narodziny w czasie pandemii. Zobacz intymny fotoreportaż z porodu domowego, https:// www.national-geographic.pl/artykul/narodziny-w-czasie-pandemii-zobacz-intymny-fotoreportaz-z-porodu-domowego.

Jelonek G., Przez film Cząstki kobiety na Netfliksie kobiety będa rezygnować z porodów w domu? Produkcja w ogniu krytyki. „Demonizuje porody domowe”, „Głos Wielkopolski” 13.01.2021, https://gloswielkopolski.pl/przez-film-czastki-kobiety-na-netfliksie-kobiety-beda-rezygnowac-z-porodow-w-domu-produkcja-w-ogniu-krytyki-demonizuje-porody/ar/c6-15387115.

Kelly H., Pieces of a Woman Hinges on One Heaving, Tremendous Home Birth-Scene, https://www. vulture.com/2021/01/how-pieces-of-a-woman-filmed-the-home-birth-scene.html.

Lockwood Ch.J., Czy w domu bezpiecznie? Chyba nie, https://podyplomie.pl/publish/system/articles/pdfarticles/000/012/941/original/36-37.pdf?1472037623.

Oszczepalińska M., Poród $w$ domu nie dla każdego! Ile trzeba zapłacić za ten komfort?, https://mamotoja.pl/porod-w-domu-ile-kosztuje-i-jak-wyglada-naturalny-porod-domowy,gdzie-rodzic-artykul,26251,rlp1.html.

Porody domowe w czasie pandemii. „,Mocne, głębokie przeżycie”, https://dziendobry.tvn.pl/a/porody-domowe-w-czasie-pandemii-mocne-glebokie-przezycie.

Poród domowy w czasie pandemii - szaleństwo czy bezpieczna alternatywa dla szpitala?, https:// poofi.com/pl/porod-domowy-w-czasie-pandemii-szalenstwo-czy-bezpieczna-alternatywa-dla-szpitala.

Poród $w$ domu — czy to duże ryzyko?, https://www.edziecko.pl/ciaza_i_porod/7,79332,20387912, porod-w-domu-czy-to-duze-ryzyko.html.

Studenckie Prace Prawnicze, Administratywistyczne i Ekonomiczne 38, 2021

(C) for this edition by CNS 